\title{
CSR Value for Consumers: Indian Perspectives
}

\author{
Basanta Kumar ${ }^{1}$, Anjali Panda ${ }^{2}$, Brajaraj Mohanty ${ }^{3}$ \\ ${ }^{1}$ Department of Business Administration, Utkal University, Bhubaneswar, India \\ ${ }^{2}$ Faculty of Marketing, DAV School of Management, Bhubaneswar, India \\ ${ }^{3}$ Faculty of Strategy, Xavier Institute of Management, Bhubaneswar, India \\ Email address: \\ babd.56210@yahoo.com (B. Kumar), anjalipanda575@gmail.com (A. Panda), brajaraj@ximb.ac.in (B. Mohanty)
}

\section{To cite this article:}

Basanta Kumar, Anjali Panda, Brajaraj Mohanty. CSR Value for Consumers: Indian Perspectives. Science Journal of Business and Management. Vol. 3, No. 3, 2015, pp. 71-76. doi: 10.11648/j.sjbm.20150303.12

\begin{abstract}
The study combining with elements of descriptive and explanatory research based on 180 respondents reports on what corporate social responsibility (CSR) is to the consumers, and the value they derive from it. Research finds that consumers clearly derive social, emotional and functional value from CSR. The research is inconclusive, and it is arguable whether CSR policy has any influence on their buying decision. However, consumers report another type of value, i.e., egocentric value that needs to be considered in future research for validation.
\end{abstract}

Keywords: Consumer Values, Consumer Perceptions, Social Responsibility

\section{Research Issues}

Research studies show that there are diverse views on the relationship between corporate social responsibility (CSR) and business. Proponents believe that CSR leads companies to make more long-term profit and achieve success $[1 ; 2 ; 3 ; 4$; $5 ; 6,7]$. The opponents argue that CSR vitiates the objective of maximization of profits $[8 ; 9 ; 10 ; 11 ; 12]$. Despite this debate, it is seen that CSR is increasing its presence in today's corporate world. Companies see ultimate long-term profitability through CSR activities [13; 14].Figure1 below shows that as organisations move from left to right on the value curve, greater returns are realized as CSR becomes more integrated into core business strategy [15]. Companies having acclaimed CSR foster desired supportive behaviours among consumers. And, the consumers buy their products, recommend the company to others or trust it to do the right thing when faced with disruptions or difficulties [16]. Researches $[17 ; 18]$ indicate that consumers care about CSR. With the growing awareness level of the role of business in the economy and society, most of the consumers expect the companies to have fairly high involvement in CSR.

Consumers are crucial stakeholders for companies. They determine the success of the company's CSR policy to a large extent. As such, understanding them is crucial. Part of understanding these customers relates to finding out why they buy from companies that incorporate social responsibilities into their business practices. Several research studies [19; 20] find that consumers only support firms engaged in CSR, if they receive some value from the exchange. They usually do not view CSR as one overall impression of a firm. However, they look instead to how each CSR activity can add to their overall value proposition when making a purchase. It indicates that consumers are still more motivated by self-interest than by the interest of the society. Consequently, corporates try to understand consumers through analyzing what kind of value(s) these consumers derive from CSR. Thus, the following research question emerges, "What is the value of corporate social responsibility for consumers?"

In Indian context, the traditional philanthropic concept of CSR has seen a change with enactment of Indian Companies Act 2013 that makes CSR mandatory for companies operating in India. Over the years companies have moved from simply traditional philanthropic to institutional building (educational, research and cultural) and now getting ready to comply with the mandatory regulations. With global influence, the Act aiming at greater transparency and disclosure makes CSR compulsory, identifies activities to be covered under CSR, stipulates amount to be invested in CSR. It also makes a provision for CSR Committee of the company to ensure effective implementation, supervision, and regulation of CSR activities. However, with the business environment getting increasingly complex with the changing 
economic environment, the stakeholders are becoming vocal about their expectations. Good CSR practices are believed to bring more and more expected benefits [21].

A first-ever Indian study on B2C with 2300 respondents across India conducted on msn.com by Lowe Lintas, MSN India, and Cross Tab prior to the new Companies Act 2013 is very relevant here. The study reveals that 57 percent of respondents trusted brands with more CSR spending than brands that did not. About 69 percent stated that they would prefer buying a brand that does CSR compared to a brand that does not. However, as high as 93 percent of the respondents viewed that they expect corporates to undertake CSR activities. They gave a reason that corporates use a lot of social resources, and CSR is the quid pro quo for this [22]. In this context, the research question about the value of CSR for consumers tries to find an answer at a micro level.

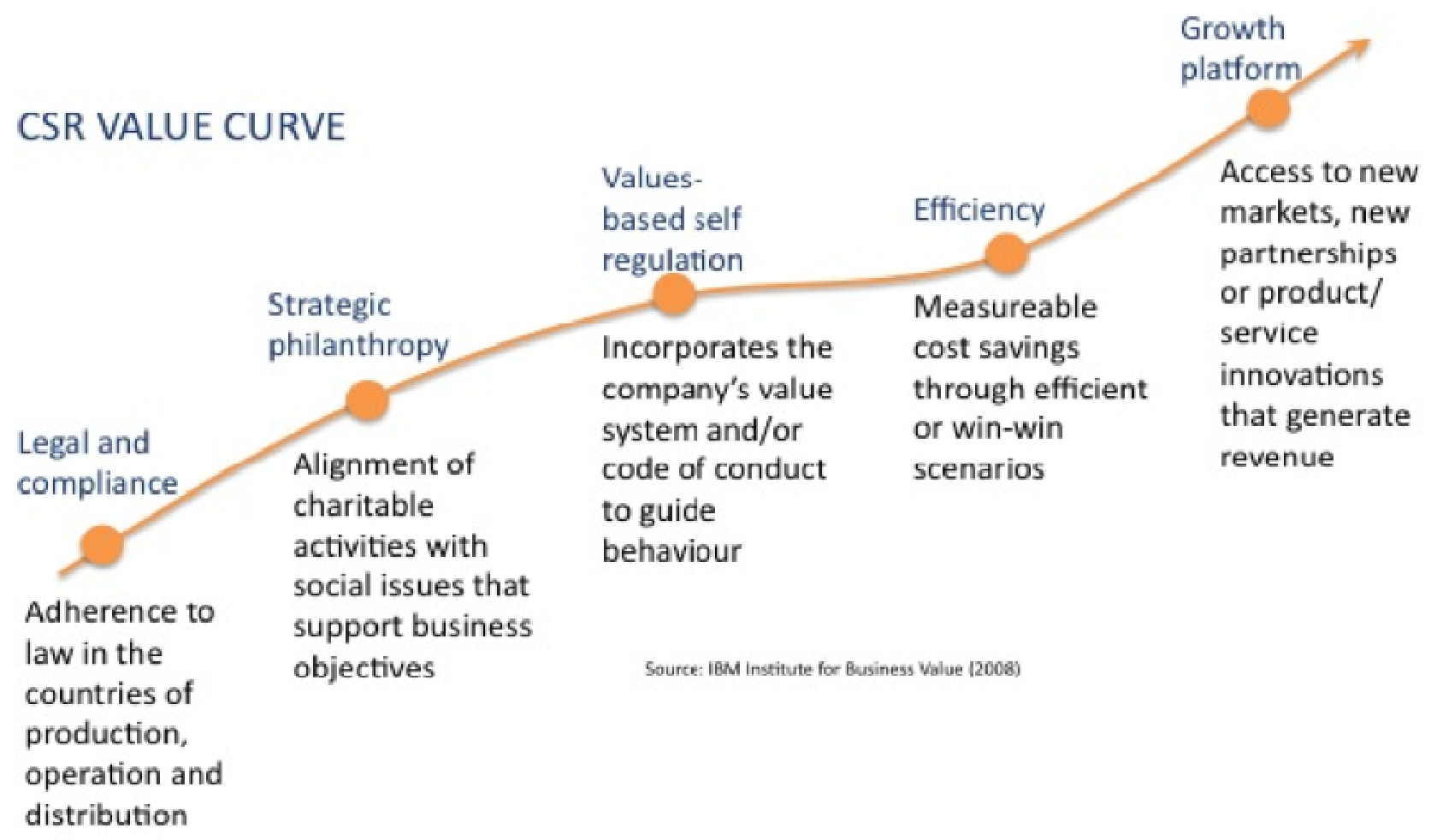

Source: www-304.ibm.com/easyaccess/fileserve?contentid=131474, Page 4

Figure 1. IBM's CSR Value Curve.

\section{Objectives}

The research objectives are to understand the consumers' perception about CSR, to identify companies' activities that consumers consider to be CSR activities and to recognize the benefits that the consumers derive from CSR.

\section{Methodology}

Against this backdrop, a combination of quantitative and qualitative research was used to investigate the views and approach of the respondents in relation to CSR and the value that they could derive from it. The research approach is mainly deductive as it starts with the literature review to find the research issue and consequently, design a research strategy to try and formulate an answer to the research question. The study combines elements of descriptive and explanatory research to report on what CSR is, and the value consumers derive from it.

Purposive sampling was adopted to select the respondents who did shopping at malls in Bhubaneswar, the capital city of
Odisha state. The sample comprised of males and females of different age groups and diverse background who shopped at the super malls like Big Bazar, Pantaloons, Reliance Fresh, and Vishal Mega Mart. The survey period was AugustSeptember 2014 much after the clarification notified by the government about the components of CSR activities. Out of 205 respondents, 172 respondents who had shopped at least one time during May-July, 2014 were retained for the study with the premise that they are believed to have information about the research exercise. A semi-structured questionnaire was used to seek information from the respondents. SPSS 18 version was used to process the data. Mainly descriptive statistics was used, and a factor analysis with ANOVA was executed to analyze the different types of value consumers derive from CSR.

\section{Findings}

\subsection{Demographic Results}

The demographic statistics of the respondents are shown in Table-1. 
Table 1. Demographic profile of the respondents $(n=172)$.

\begin{tabular}{|c|c|c|}
\hline $\begin{array}{l}\text { Demographic } \\
\text { features }\end{array}$ & Variables & $\begin{array}{l}\text { Percentage of } \\
\text { respondents }\end{array}$ \\
\hline \multirow{3}{*}{ Gender } & Male & 39 \\
\hline & Female & 61 \\
\hline & Total & 100 \\
\hline \multirow{4}{*}{ Age } & $20<25$ years & 48.84 \\
\hline & $25-30$ years & 36.05 \\
\hline & $>40$ years & 15.11 \\
\hline & Total & 100 \\
\hline \multirow{4}{*}{ Education } & Graduate & 42 \\
\hline & Post Graduate & 41.33 \\
\hline & Others & 8.67 \\
\hline & Total & 100 \\
\hline \multirow{6}{*}{ Occupation } & Service & 38.95 \\
\hline & Students & 31.40 \\
\hline & Profession & 13.37 \\
\hline & Business & 9.88 \\
\hline & Household & 6.40 \\
\hline & Total & 100 \\
\hline \multirow{6}{*}{$\begin{array}{l}\text { Shopping at } \\
\text { Mall }\end{array}$} & Less than once a month (Group 1) & 6.98 \\
\hline & Once a month (Group 2) & 14.53 \\
\hline & Once in every two weeks (Group 3) & 22.09 \\
\hline & Once a week (Group 4) & 25.58 \\
\hline & Several times a week (Group 5) & 30.82 \\
\hline & Total & 100 \\
\hline
\end{tabular}

Source: Primary data

From the analysis, it was found that maximum respondents were female $(61 \%)$ and were less than 25 years of age $(49 \%)$. About 83 percentages of the respondents were either graduates or post graduates. About occupation, 39 percent were service holders followed by students with 31 percent. Regardingthe frequency of shopping at malls, it shows that the largest group consisting of 31 percent responded shopped at a mall several times a week followed by 26 percent once a week. This finding appears to be a good result because it means that we did just reach the occasional buyers with our questionnaires.

\subsection{Analysis of Research Results}

\subsubsection{Consumers' Perception about CSR}

To find out what respondents consider to be CSR, they were asked to give three words that came to their mind or that they associated with CSR. While all respondents affirmed that they knew about CSR (activity), only 21.51 percent clearly provided three words, but all others provided at least one word. Their responses were coined under six broad headings viz., environmental, social, economic, stakeholder, voluntariness, and future. Maximum respondents $(69 \%)$ referred to the environmental dimension.

\subsubsection{Companies' Activities that Consumers Consider to be CSR Activities}

The respondents were given a list of activities as provided in Schedule VII of the Companies Act 2013 to indicate the ones they believed to be CSR activities. As high as 79 percent indicated those were ensuring sustainable environment protection, poverty eradication, and employment generation, and educational promotion were the three top CSR activities. Contribution to Prime Minister's Relief Fund or similar fund (s) as CSR activity was not perceived well by many of the respondents $(63 \%)$.

\subsubsection{Types of Value Consumers Derive from CSR}

A factor analysis with ANOVA was executed to understand the types of value consumers derive from CSR and whether consumers derive CSR is linked to demographic features (Annexure-1 and 2). Based on Green and Peloza [18] the questionnaire in five points Likert-style rating scale ranging from completely disagree to agree entirely was applied. KMO value of 0.809 justifies our sample adequacy. Bartlett's Test of Sphericity value of $<0.001$ explains that all items are perfectly correlated with themselves. The data passes the reliability test with Cronbach's Alfa value of .843 .

The analysis suggests that there is a significant difference between group 1 respondents (who shop less than once a month) and group 2 (who go once a month) and 1 and 4 (who go once a week). But no significant difference between other groups is found.

All groups of respondents classified based on how often they go to Mall, do not significantly differ in the emotional, functional and supply value they derive from CSR.

1. The three different groups of respondents, classified based on whether the CSR policy influences their decision to shop there, significantly differ in the social, emotional and functional value they derive from CSR.

2. Group 3 (I find CSR important, but don't consider it in my purchase decision) and group 5 (I find CSR very important and do consider it in my purchase decision) significantly differ in how they score on social, emotional, functional and supply value.

3. Group 4 (I find CSR important and sometimes consider it in my purchase decision) and group 5 (I find CSR very important and do consider it in my purchase decision) only significantly differ in how they score on emotional and functional value

\section{Discussion and Conclusion}

The findings show that consumers associate CSR most often with the environment. These revelations are not in line with Dahlsrud's (2008) study [23] that explains the least presence of the environmental dimension in all the existing definitions in the literature. The divergent views found in the literature and the views of the respondent's consumers only results in the confusion that companies are witnessing.

The study reveals that consumers do not always recognize the CSR activities of companies as CSR activities. They recognize product-related activities most often while the philanthropy categories are least recognized. These findings support the earlier observations of Panda and Kumar [24] in 
their study on 'product attributes and purchase decision'. Users indirectly indicate that they find CSR important as the activities they perceive as the most important for companies to engage in. Comparatively a low awareness level of the respondents regarding different CSR activities was observed.

Research finds that five different types of value consumers can derive from CSR: emotional value, egocentric behavior value, social value, functional value, and supply value. The results regarding the two latter types of value are rather weak so further research will be necessary to this area. The benefits consumers derive from CSR does not have the connection with their demographics. Further, the level of knowledge they have of CSR and their frequencies of shopping at malls do not have an impact on the benefit they expect from it. However, the findings indicate that the higher the influence the CSR policy has on a consumer's decision to shop at the mall, the greater the emotional, social and functional value they receive from it. Similarly, the more important the customer finds CSR, the higher the emotional, social and functional value they get from it and the lower the supplied value.

We believe there to be five distinct types of value consumers can derive from CSR, viz emotional value, social value, functional value, supply value, and egocentric behavior value. The results regarding the two latter types of value are rather weak, so further research is necessary.

However, we observed that demographics is not a good predictor of the type of value consumers derived from CSR; also, they have a low level of knowledge of CSR. As such, the frequency of visit to the shopping malls does not seem to have an impact on the value they derive from CSR. However, the results explain that the higher the influence the CSR policy has on a consumer's decision to shop at malls, the higher the social, emotional and functional value they derive from it. Similarly, more important the consumer finds CSR, the higher the emotional, functional and social value they derive from it and the lower the supplied value. We have to be careful with these conclusions though because there was no significant difference found between all the different groups.

Another significant question addressed in the study is whether the CSR policy of a company has any impact on a consumer's purchase decision and behavior. Due to growing importance of consumers as main stakeholders among business, research that examines the effects of CSR on profitability is particularly informative to organization for profitability and sustainability. The study revealed that consumers do not seem to be fully aware of all facets and all CSR activities companies are engaged. And not all domains of CSR are of equal importance. The results are found to be inconsistent and contradictory to some extent. Hence, it is inconclusive and arguably that whether the CSR policy has any influence on their decision.

Researchers are careful with these conclusions though there was no significant difference found between all the different groups. However, the research is expected to contribute to a better understanding of the complex consumer regarding the value they derive from CSR.

\section{Annexure 1. Types of Value Consumers Derive from CSR}

\section{Factor Analysis}

KMO and Bartlett Test

\begin{tabular}{lll}
\hline Kaiser- Meyer- Olkin Measure of Sampling Adequacy & & $\mathbf{. 8 0 9}$ \\
\hline & Approximate chi-square & \\
Bartlett test of Sphericity & df & 228 \\
& Sig. & .000 \\
\hline
\end{tabular}

Reliability Statistics

\begin{tabular}{lll}
\hline Cronbach's Alfa & Cronbach's Alfa Based on Standardized Items & N of Items \\
\hline .843 & .845 & 20 \\
\hline
\end{tabular}

Total Variance Explained

\begin{tabular}{|c|c|c|c|c|c|c|c|c|c|}
\hline \multirow[b]{2}{*}{ component } & \multicolumn{3}{|c|}{ Initial Eigen Values } & \multicolumn{3}{|c|}{ Extraction Sums of Square Loadings } & \multicolumn{3}{|c|}{ Rotation Sums of Square Loadings } \\
\hline & Total & $\%$ of variance & Cumulative \% & Total & $\begin{array}{l}\% \text { of } \\
\text { variance }\end{array}$ & $\begin{array}{l}\text { Cumulati } \\
\text { ve } \%\end{array}$ & Total & $\%$ of variance & Cumulative \% \\
\hline 1 & 6.589 & 27.453 & 27.453 & 6.589 & 27.453 & 27.453 & 4.165 & 17.356 & 17.356 \\
\hline 2 & 2.451 & 10.214 & 37.667 & 2.451 & 10.214 & 37.667 & 3.484 & 14.516 & 31.871 \\
\hline 3 & 1.857 & 7.736 & 45.403 & 1.857 & 7.736 & 45.403 & 2.612 & 10.885 & 42.756 \\
\hline 4 & 1.494 & 6.225 & 51.629 & 1.494 & 6.225 & 51.629 & 1.731 & 7.211 & 49.967 \\
\hline 5 & 1.121 & 4.670 & 56.298 & 1.121 & 4.670 & 56.298 & 1.401 & 5.836 & 55.803 \\
\hline 6 & 1.045 & 4.356 & 60.654 & 1.045 & 4.356 & 60.654 & 1.164 & 4.851 & 60.654 \\
\hline 7 & .984 & 4.295 & 64.949 & & & & & & \\
\hline 8 & .920 & 3.956 & 68.905 & & & & & & \\
\hline
\end{tabular}




\begin{tabular}{|c|c|c|c|c|c|c|c|c|c|}
\hline \multirow[b]{2}{*}{ component } & \multicolumn{3}{|c|}{ Initial Eigen Values } & \multicolumn{3}{|c|}{ Extraction Sums of Square Loadings } & \multicolumn{3}{|c|}{ Rotation Sums of Square Loadings } \\
\hline & Total & $\%$ of variance & Cumulative \% & Total & $\begin{array}{l}\% \text { of } \\
\text { variance }\end{array}$ & $\begin{array}{l}\text { Cumulati } \\
\text { ve } \%\end{array}$ & Total & $\%$ of variance & Cumulative \% \\
\hline 9 & .818 & 3.728 & 72.633 & & & & & & \\
\hline 10 & .765 & 3.539 & 76.172 & & & & & & \\
\hline 11 & .689 & 3.302 & 79.474 & & & & & & \\
\hline 12 & .637 & 3.107 & 82.581 & & & & & & \\
\hline 13 & .586 & 2.872 & 85.453 & & & & & & \\
\hline 14 & .489 & 2.748 & 88.201 & & & & & & \\
\hline 15 & .392 & 2.631 & 90.832 & & & & & & \\
\hline 16 & .343 & 2.446 & 93.278 & & & & & & \\
\hline 17 & .318 & 2.040 & 95.318 & & & & & & \\
\hline 18 & .256 & 1.933 & 97.245 & & & & & & \\
\hline 19 & .222 & 1.432 & 98.677 & & & & & & \\
\hline 20 & .183 & 1.323 & 100 & & & & & & \\
\hline
\end{tabular}

\section{Annexure 2: Consumers' Derive from CSR Linkage to Demographic Features}

\section{ANOVA}

Test of Homogeneity of variances

\begin{tabular}{lllll}
\hline & Levene Statistics & df1 & df2 & \\
\hline social_value & .192 & 2 & 160 & .828 \\
emotional_value & 1.389 & 2 & 160 & .254 \\
functional_value & 1.792 & 2 & 135 & 160 \\
supply & 2.358 & 2 & .183 & .098 \\
\hline
\end{tabular}

\begin{tabular}{|c|c|c|c|c|c|}
\hline & Sum of squarers & df & Mean squares & $\mathbf{F}$ & Sig. \\
\hline social_valueBetween Groups & 4.484 & 2 & 2.242 & 5.095 & 0.014 \\
\hline Within Groups & 70.464 & 160 & .440 & & \\
\hline Total & 74.948 & 162 & & & \\
\hline emotional_valueBetween Groups & 8.264 & 2 & 4.132 & 15.651 & 0.000 \\
\hline Within Groups & 42.334 & 160 & .264 & & \\
\hline Total & 50.598 & 162 & & & \\
\hline functional_valueBetween Groups & 3.182 & 2 & 1.591 & 5.82 & 0.018 \\
\hline Within Groups & 36.884 & 135 & .273 & & \\
\hline Total & 40.066 & 137 & & & \\
\hline supply Between Groups & 6.564 & 2 & 3.282 & 5.407 & .007 \\
\hline Within Groups & 97.082 & 160 & 0.607 & & \\
\hline Total & 103.646 & 162 & & & \\
\hline
\end{tabular}

\section{References}

[1] Craps, M (2012). CSR theories [Power Point slides]. Retrieved from www.hubwise.be also see Craps, M. (2012). Introduction to CSR [Power Point slides]. Retrieved from www.hubwise.be, Accessed on February 22, 2015

[2] Post, J. E., Preston, L.E., \& Sachs, S.(2002). Managing the extended enterprise: The new stake holder view. California Management Review, 45(1), 6-28.

[3] Carroll, A.B.(2001).The pyramid of corporate social responsibility: toward the moral management of organizational stakeholders. Business Horizons, 34(4),pp.39-48.
[4] Elkington, J. (1997). Cannibals with Forks: The triple bottom line of 21 stcentury business. Oxford: Capstone Publishing Limited.

[5] Davis, K. (1960). Can business afford to ignore social responsibilities? California Management Review,2 (3),70-76.

[6] Davis, K.(1973). The case for and against business assumption of social responsibilities. Academy of Management Journal, 16(2),312-322.

[7] Davis, K., \& Blomstrom, R.L. (1971).Business, society, and environment: social power and social response. New York: McGraw-Hill.

[8] Porter, M.E., \& Kramer, M.R. (2011).Creating shared value. Harvard Business Review, 89 (1),62-77. 
[9] Buhr, H., \& Grafström, M. (2007). The making of meaning in the media: The case of corporate social responsibility in the Financial Times. In F.den Hond, F.G.de Bakker, \& P. Neergaard (Eds.). Managing corporate social responsibility in action: Talking, doing and measuring (pp.15-32). Aldershot: Ashgate Publishing Limited

[10] Margolis, J. D., \& Walsh, J. P. (2003). Misery loves companies: Rethinking social initiatives by business. Administrative Science Quarterly,48 (2), 268-305

[11] Jensen, M. (2002). Value maximization, stakeholder theory, and the corporate objective function. Business Ethics Quarterly, 12(2), 235-256.

[12] Friedman, M. (1970). The social responsibility of business is to increase its profits. The New York Times Magazine.1-6

[13] Peloza, J., \& Shang, J. (2011). Investing in CSR to enhance customer value. Director Notes of the Conference Board,3(3),1-

10.Retrievedfromhttp://papers.ssrn.com/sol3/papers.cfm?abstr act id $=1843308$, Accessed on February 25

[14] Kotler, P., \& Lee, N. (2005). Corporate Social Responsibility: Doing the most good for your company and your cause. Hoboken, New Jersey: John Wiley \& Sons Inc.

[15] IBM (2008), Attaining sustainable growth through corporate social responsibility, Retrieved from www304.ibm.com/easyaccess/fileserve? contentid $=131474$ on March 12, 2015

[16] Reputation Institute (2014), Global CSR Rep Trak®Ranking, http://www.reputationinstitute.com/about-reputationinstitute/the-reptrak-framework, Accessed on March 17, 2015

[17] Mohr, L. A., Webb, D.J., \& Harris, K. E. (2001). Do consumers expect companies to be socially responsible? The impact of corporate social responsibility on buying behavior. Journal of Consumer Affairs, 35(1), 45-72.

[18] Boulstridge, E., \& Carrigan, M. (2000). Do consumers really care about corporate responsibility? Highlighting the attitudebehaviour gap, Journal of Communication Management, 4(4),pp.1-22.

[19] Green, T., \& Peloza, J.(2011). How does corporate social responsibility create value for consumers? Journal of Consumer Marketing, 28(1),48-56

[20] Bhattacharya, C.B., \& Sen, S.(2004). Doing better at doing good: when, why and how consumers respond to corporate social initiatives. California Management Review, 47(1),9-4.

[21] CII, (2013), Handbook on Corporate Social Responsibility in India, www.pwc.in, Accessed on February 12, 2015. Also read India's New Corporate Social Responsibility Requirements Beware of the Pitfalls, April 2014, http://www.jonesday.com/Indias-New-Corporate-SocialResponsibility-Requirements--Beware-of-the-Pitfalls-04-152014/

[22] Kompella Kartikeya, (2011), CSR: Cause-related branding can help balance business with marketing, December 1, 2011, $\mathrm{http}: / /$ businesstoday.intoday.in/story/corporate-socialresponsibility-business-marketing-balance/1/20574.html, accessed on February 10, 2015

[23] Dahlsrud, A. (2008), How corporate social responsibility is defined: an analysis of 37 definitions. Corporate Social Responsibility and Environment Management, 15(1), 1-13.

[24] Panda, A., Kumar, B. (2015), Factors Determining Retail Customer Satisfaction: A Study of Organised Retail Outlets in an Indian Capital City, International Journal of Management and Development Studies, Volume No. 4 (2015), Isuue No. 1, January, 92-101 